\title{
The Value at Risk of Selling Option on Crude Oil West Texas Intermediate
}

\author{
Abitur Asianto', Hermanto Siregar', Roy Sembel ${ }^{3}$, \\ Tubagus Nur Ahmad Maulana ${ }^{4}$
}

\begin{abstract}
The Value at Risk (VaR) of selling the option on crude oil WTI has not widely known, whereas this trade is the most significant transactions in the world. This study aimed to analyze the Value at Risk (VaR) of the far out of the money (FOTM) and the in the money (ITM) strike position of selling option on crude oil WTI investment. The monthly option premium return data ranging from April 1984 to May 2017 was analyzed by the ARCHGARCH and VaR method to get the risk of FOTM and ITM strike position. Empirical results indicate that the risk of the FOTM strike was much lower than the ITM strike positions. It meant that selecting the FOTM strike position of the selling option on crude oil WTI investment could be considered by stakeholders because its risk was much lower than the ITM strike position.
\end{abstract}

Keywords: value at risk, option, ARCH-GARCH

JEL Classification: C32, G19, G32

\begin{abstract}
Abstrak. Nilai risiko (Value at Risk/VaR) pada penjualan opsi minyak mentah WTI belum banyak diketahui, padahal perdagangan ini merupakan transaksi terbesar di dunia. Penelitian ini bertujuan untuk menganalisis nilai risiko pada posisi strike di the far out of the money (FOTM) dan di the in the money (ITM) pada investasi penjualan opsi minyak mentah WTI. Data imbal hasil premi opsi bulanan mulai dari bulan April 1984 sampai Mei 2017 dianalisis dengan metode ARCH-GARCH dan VaR untuk mendapatkan nilai risiko pada posisi strike FOTM dan ITM. Hasil empiris menunjukkan bahwa nilai risiko pada posisi strike FOTM jauh lebih rendah daripada risiko di posisi strike ITM. Hal ini menunjukkan bahwa pemilihan posisi strike FOTM pada investasi penjualan opsi minyak mentah WTI dapat dipertimbangkan oleh pemangku kebijakan karena risikonya jauh lebih rendah daripada risiko di posisi strike ITM.
\end{abstract}

Kata Kunci: value at risk, option, ARCH-GARCH

\section{How to Cite:}

Asianto, A., Siregar, H., Sembel, R., \& Maulana, T. N. A. (2019). The Value at Risk of Selling Option on Crude Oil West Texas Intermediate. Etikonomi: Jurnal Ekonomi. Vol. 18 (1): 105 - 120. doi: http//dx.doi.org/10.15408/etk.v18i1.7319. 


\section{Introduction}

The crude oil West Texas Intermediate (WTI) traded on the Chicago Mercantile Exchange \& Chicago Board of Trade (CME Group) through futures or options transactions. These transactions have increased significantly to more than 100,000 contracts per day today. It shows that WTI commodity is one of the world's macroeconomic indicators (Behmiri \& Manso, 2013).

The US option is the most active and the most significant option transaction in the world. There is four basic options strategy, namely, buy the call option, sell a call option, buy a put option and sell put option (Cordier \& Gross, 2009). Buy call option (long call option) on WTI is an option contract that has rights (not obligation) to buy underlying WTI at strike price before the expiry date. Buy put option (long put option) on WTI is an option contract having rights (not obligation) to sell underlying WTI at strike price before the expiry date. The holder of this contract is called the option holder. Sell call option (short call option) or sell put option (short put option) are a writer of the option contract. The option writer should exercise if their margin trading is out of the limits (Cordier \& Gross, 2009).

Selling option can do on some strike positions. There are many choices in trading options strike positions starting from the closest strikes position to the current underlying price namely the ITM strike position, to the further position away from the current underlying price namely the FOTM strike position (Asianto, 2014). This position shows in Figure 1 and Figure 2.

Figure 1. Sell call option at ITM and FOTM strike

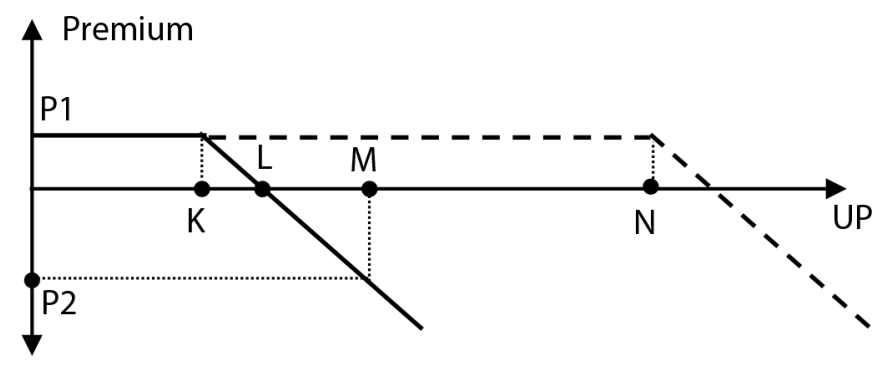

Figure 2. Sell put option at ITM and FOTM strike

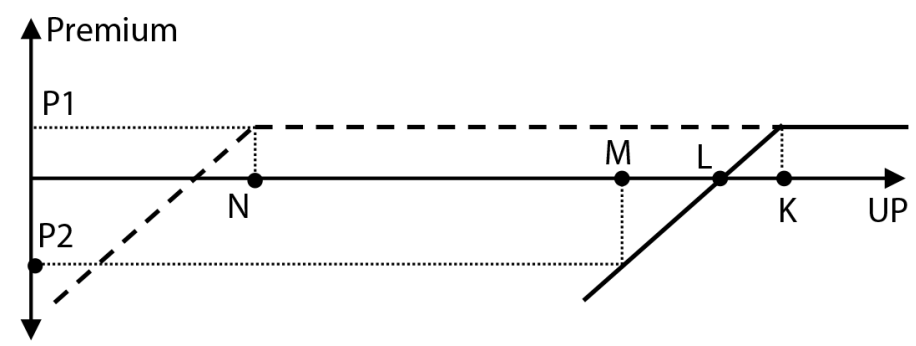

Where UP is underlying prices, $\mathrm{K}$ is the current underlying price; Premium is option premium, $\mathrm{P} 1$ is current option premium, $\mathrm{P} 2$ is option premium on the expired date, $\mathrm{L}$ is the breakeven point, $\mathrm{M}$ is ITM strike, $\mathrm{N}$ is FOTM strike. 
Figure 1 shows that we can open the sell call option on strike K at ITM position. We can also open the sell call option on strike $\mathrm{N}$ at FOTM position. If the underlying price (UP) increases over $\mathrm{L}$ and reaches $\mathrm{M}$ on the expiry date, then the issuer of sell call option with strike K must pay P2, while the seller call option at strike $\mathrm{N}$ will get the profit of the option premium (P1) because the underlying price has not reached strike $\mathrm{N}$.

Figure 2 shows that we can open the sell put option on strike $\mathrm{K}$ at ITM position. We can also open the sell put option on strike $\mathrm{N}$ at FOTM position. If the underlying price (UP) decreases over $\mathrm{L}$ and reaches $\mathrm{M}$ on the expiry date, then the issuer of sell put option with strike K must pay P2, while the seller put option at strike $\mathrm{N}$ will get the profit of the option premium (P1) because the underlying price has not reached strike $\mathrm{N}$.

According to Mugwagwa et al., (2011), the Black-Scholes option pricing model (BSOPM) is the most famous option-pricing model. We used it to calculate the monthly return of selling option premium using daily WTI price data. This equation is as follows:

$$
\begin{array}{lll}
\mathrm{C}=\mathrm{S} \cdot \mathrm{N}\left(\mathrm{d}_{1}\right)-\mathrm{X} \cdot \mathrm{e}^{-\mathrm{rt}} \cdot \mathrm{N}\left(\mathrm{d}_{2}\right) & (1) & P=X \cdot e^{-r t} \cdot N\left(-d_{2}\right)-S \cdot N\left(-d_{1}\right) \\
\mathrm{d}_{1}=\frac{\ln (\mathrm{S} / \mathrm{X})+\left(\mathrm{r}+0.5 \mathrm{~s}^{2}\right)(\mathrm{t})}{\mathrm{s} \sqrt{\mathrm{t}}} & (2) & d_{2}=d_{1}-s \cdot \sqrt{t}
\end{array}
$$

Where $\mathrm{C}$ is call option premiums; $\mathrm{P}$ is put option premium; $\mathrm{S}$ is current WTI price, $\mathrm{X}$ is WTI strike price, $\mathrm{r}$ is risk free rate, $\mathrm{t}$ is expiry time (year), $\mathrm{N}$ is cumulative standard normal distribution, $\varepsilon$ is exponential term, $\ln$ is natural logarithm and $s$ is standard deviation.

According to Chicago Mercantile Exchange \& Chicago Board of Trade (CME Group), the trade option on WTI is one of the most significant trading in the world. Option trading took place between seller options and buyer options. The number of studies of the buying option should be as same as the selling options, but in fact, the existing option studies were dominated by buying options compared to selling options. Thomsett (2008), Clarke \& Clarke (2012), Saliba et al., (2008), and Augen (2010) considered the selling option had a limited return in unlimited risks. They preferred to use buying option strategy because it could obtain unlimited returns in a relatively low premium fund.

Conversely, research on selling options was still a few. Some researchers claimed that the selling options investment if done at the FOTM strike had a smaller risk and higher performance than buying option investment. Summa \& Lubow (2002), Cordier \& Gross (2009), Asianto (2014) stated that selling option investments if done in the right way, can have better winning probability, lower risk and higher performance than buying option investments. The selling option performance could be positive above the market. Asianto (2014) explained that the risk of selling the option on WTI at far out of the money (FOTM) strikes was lower than the in the money (ITM) strikes. The risk of selling option on WTI has not widely known.

This fact indicated that the risk of selling options on WTI investment needed to be analyzed more in-depth in order to improve the performance of the portfolio and to decrease 
the WTI market volatility level. This study needed to be done to consider economics, trade policymakers, and stakeholders should prioritize the risk analysis first before doing profitability analyzing. Knowing the risk level of investment could increase portfolio performance conservatively.

This study aimed to examine the risk of selling options on WTI more deeply through the analysis of the risk of FOTM and ITM strike position of selling option on WTI investment. We used Autoregressive Conditional Heteroscedasticity-Generalized Autoregressive Conditional Heteroscedasticity (ARCH-GARCH) method. Li et al., (2016), He et al., (2012), and Marimoutou et al., (2009) did this method of analysis.

The range of data used in this study was significant than previous research. The data used daily WTI price ranged from April 1984 to May 2017. This daily WTI price data were analyzed by the Black-Scholes Option Pricing Model to become the monthly return of selling option on WTI premium. We chose the strikes at FOTM position of strike 9, 10, -9, and -10 . We also chose strikes at ITM positions of strike $1,2,-1$, and -2 . We compare the value at risk between ITM and FOTM strikes. The range of research data is broader than previous research. This method of collecting data was more comprehensive than previous research method, so it supported the novelty of this research.

Empirical results indicated that during the study period the value at risk of FOTM strikes of selling options on WTI was much lower than ITM. There has been no research on this so that these results are a novelty of research. This study expected to advance the science of financial and investment of commodities, and as an input for the financial services authority $(\mathrm{OJK})$ in the development of derivatives and futures markets in Indonesia.

\section{Methods}

Selling option could do with various underlying listed in futures and stocks in the United States market, but this selling option research did with underlying WTI. The daily WTI price ranged from April 1984 to May 2017 data was downloaded from https://www. quandl.com/. This daily WTI price data were analyzed by the Black-Scholes Option Pricing Model to become the monthly return of selling option on WTI premium.

In this study, we calculated the premium of selling call option $(\mathrm{C})$ in each strike by using BSOPM at the beginning of each month. After the investment run to 1-month expiration period, we calculated the premium return of selling option investment with the following stages.

$$
\begin{aligned}
& \Delta W T I_{\text {call }}=S-X \\
& \text { If } \Delta W T I_{\text {call }} \leq 0 \rightarrow R_{\text {call }}=C \\
& \text { If } \Delta W T I_{\text {call }} \geq 0 \rightarrow R_{\text {call }}=C-\Delta W T I_{\text {call }}
\end{aligned}
$$

Where $\Delta$ WTIcall is the WTI price difference between the WTI market price (S) and the WTI strike price (X). If $\Delta$ WTIcall is lower or equal to zero, the return of the sold call option 
(Rcall ) will be equal to the call option premium (C). If $\Delta$ WTIcall is higher than zero, the return of the sold call option (Rcall) will be equal to the call option premium (C) minus $\Delta$ WTIcall.

We also calculated calculate the premium of selling put option $(\mathrm{P})$ in each strike by using BSOPM at the beginning of each month. After the investment run to 1-month expiration period, we calculated the return of selling a put option with the following stages.

$$
\begin{aligned}
& \Delta W T I_{p u t}=X-S \\
& \text { If } \Delta W T I_{p u t} \leq 0 \rightarrow R_{p u t}=P \\
& \text { If } \Delta W T I_{p u t} \geq 0 \rightarrow R_{p u t}=P-\Delta W T I_{p u t}
\end{aligned}
$$

Where $\Delta$ WTIput is the WTI price difference between WTI strike price (X) minus the WTI market price (S). If $\Delta$ WTIput is lower or equal to zero, the return of sell put option (Rput ) will be equal to the put option premium (P). If $\Delta$ WTIput is higher than zero, the return of the sell put option (Rput) will be equal to the put option premium (P) minus $\Delta$ WTIput.

To compared the value at risk of each strikes required the return premium of each strike of selling option from the crude oil WTI price data analyzed using BSOPM. We used daily WTI price ranging from April 1984 to May 2017. This data was analyzed using BSOPM to become the monthly option premium return. We chose four strike position namely ITM of strike 1, 2, -1 and -2 . We also chose four strike position namely FOTM of strike $9,10,-9$, and -10 . The form is calculating the monthly return of selling the option at each strike ranging from April 1984 to May 2017, and we had eight strikes contained each monthly return series data. These data were analyzed to get the value at risk of each strike.

Autoregressive Conditional Heteroscedasticity (ARCH) introduced by Engle in 1982 to overcome this problem by analyzing the volatility of the time series economic data. This volatility reflected in a residual variance that did not meet the assumption of homoscedasticity or residual variance constant over time. Bollerslev (1986) developed an ARCH to Generalized Autoregressive Conditional Heteroscedasticity (GARCH). This GARCH was the time series data using past variants for forecasting future variants.

The variant of the error GARCH method consisted of three components namely the constant variety $(\alpha 0)$, the volatility of the previous period or called the ARCH $(e 2 t-i)$, and the variance of previous or called the GARCH $(\sigma 2 \mathrm{t}-\mathrm{j})$. Similar to the ARCH model, in order for the variance to be positive $\{\operatorname{var}(\mathrm{et})>0\}$, this model should also make as a restriction of $\alpha 0>0$, $\alpha 1$ and $\lambda 1 \geq 1$, and $\alpha 1+\lambda 1<1$ which can estimate with maximum likelihood technique. The equation was:

$$
\begin{aligned}
& \sigma_{t}^{2}=\alpha_{0}+\alpha_{1} e_{t-1}^{2}+\ldots \ldots+\alpha_{p} e_{t-p}^{2}+\lambda_{1} \sigma_{t-1}^{2}+\ldots \ldots+\lambda_{q} \sigma_{t-q}^{2} \text { or } \\
& \sigma_{t}^{2}=\alpha_{0}+\sum_{i=1}^{p} \alpha_{i} e_{t-i}^{2}+\sum_{j=1}^{q} \lambda_{j} \sigma_{t-j}^{2}
\end{aligned}
$$


Where $\sigma 2 \mathrm{t}$ is conditional variance, $(\mathrm{a} 0, \mathrm{a} 1, \lambda 1)$ are constants, $\mathrm{e} 2 \mathrm{t}-\mathrm{i}$ is squared error of previous period, $\sigma 2 \mathrm{t}-\mathrm{j}$ is a conditional variance of the previous period, $\mathrm{p}$ is lags of squared error, $\mathrm{q}$ is lags of conditional variance, and $(i, j)$ are $0,1,2, \ldots . . n$. The model in this equation is called the GARCH model (p, q).

According to Jorion (2011), Value at Risk (VaR) in the financial context is a risk estimate, with a certain degree of confidence, how much the portfolio can lose over a given time horizon. VaR is a measure of downside risk that concentrated on the low probability occurrence that occurs at the bottom tail of the distribution. The critical value of the portfolio period is determined as the worst value at the end period of a portfolio that may occur with a predetermined level of confidence " 1 - c", such as by $95 \%$ or $99 \%$. This worst value is assumed not more than $\mathrm{c}$ percent of the time. This result implies that under normal market conditions, only $5 \%$ of the time, portfolio losses will exceed 1 million dollars. VaR describes the quantile distributions of profits and losses projected above the horizon target. The VaR concept is based on statistical observations of historical data and is relatively objective. VaR equation is as follows (Jorion, 2011).

$$
\operatorname{VaR}=\left(\sigma_{t+1} \cdot \sqrt{b}\right) \cdot Z_{\alpha} \cdot W
$$

Where $\mathrm{VaR}$ is the magnitude of risk, $\mathrm{b}$ is the investment period, $\mathrm{Z} \alpha$ is the critical point in table $\mathrm{Z}$ with $95 \%$ confidence interval, $\mathrm{W}$ is the value of the investment, $\sigma \mathrm{t}$ is the $\mathrm{t}$ ahead standard deviation.

This study used ARCH-GARCH to get an optimal model of each strike of selling option on WTI. VaR analysis did by ARCH-GARCH approach. The model is used to analyze the VaR of each strike of selling option on WTI. This research used Eviews and Minitab software to analyze the data. First, this research analyzed the statistical descriptive of all variables to determine whether the data has an ARCH effect and whether the data normally distributed. The unit root test analyzed for the stationary of each variable. Then this research used the correlogram test to determine whether the data has a serial correlation. After that, this research runs the ARCH-GARCH model estimation to analyze the optimal model and check using ARCH Lagrange Multiplier Test (ARCH-LM Test) to analyze the ARCH-GARCH model obtained whether it is free from serial correlation and ARCH effects. Finally, This research performed VaR analysis to measure the risk of each variable.

\section{Result and Discussion}

All Return Values in All Strikes Experienced the Deepest Decline in 2009. All returns graph of all strikes could show in Figure 3. Figure 3 explained that all strikes had several similar shocks, which was understandable because they based on the same underlying. The most profound shock occurred in 2009 where at that time the WTI prices surged to USD 140 per barrel through 2008, fell in 2009. The WTI price fluctuated until early 2017. This result showed that the selling option on WTI also shaken due to WTI oil price shocks. 
Figure 3. All strike had the same deepest decline in 2009

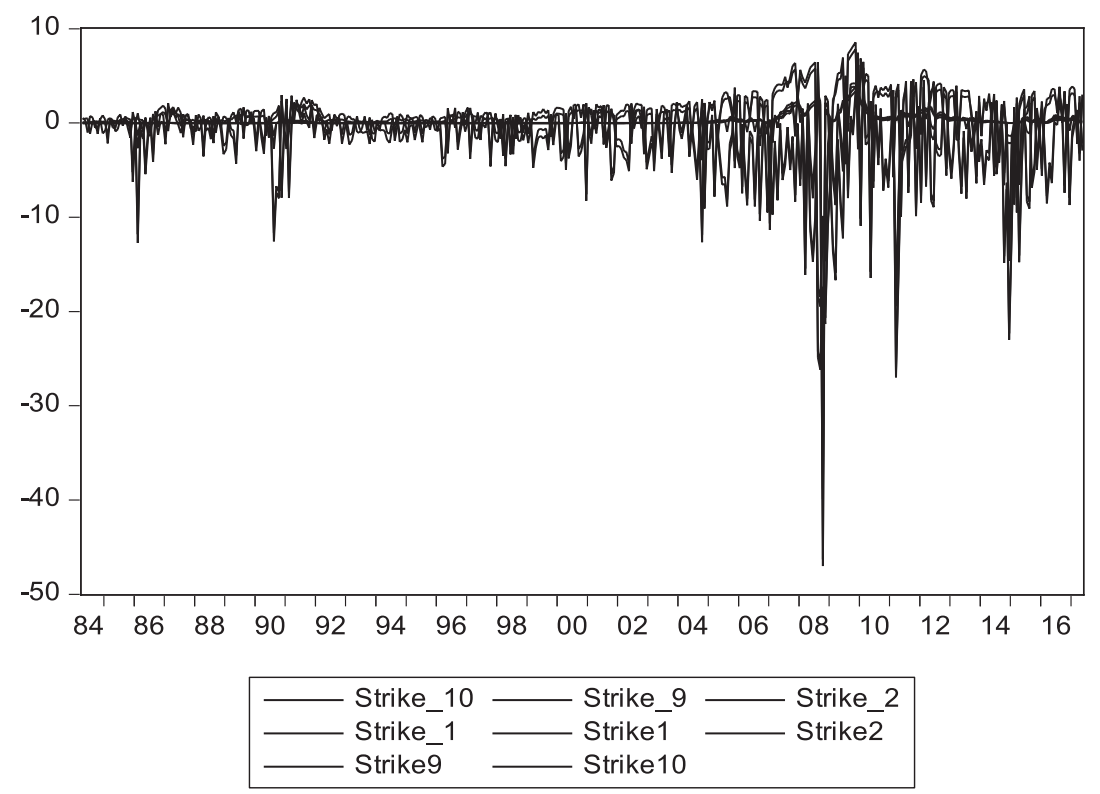

Descriptive Analysis Showed that the Data had an ARCH Effect. First of all, we analyzed all strikes data to find whether the ARCH effect. The descriptive analysis result due to 8 strikes shows in Table 1 . Table 1 explains that all skewness values are lower than $0(<0)$, so that the variable suspected of having an ARCH effect. All kurtosis values are higher than three, and all probabilities data are less than 0.05 so that the data distribution is not normal and has an ARCH effect. The data is suspected of being heteroscedasticity and has an ARCH effect.

Table 1. The data had an ARCH effect

\begin{tabular}{|c|c|c|c|c|c|c|c|c|}
\hline Strike & -10 & -9 & -2 & -1 & 1 & 2 & 9 & 10 \\
\hline Std. Dev. & 1.83 & 2.02 & 3.93 & 4.29 & 4.38 & 4.23 & 2.6 & 2.43 \\
\hline Skewness & -7.29 & -6.75 & -3.02 & -2.6 & -3.92 & -4.28 & -10.48 & -11.55 ARCH \\
\hline Kurtosis & 64.18 & 56.83 & 16.68 & 13.65 & 33.72 & 37.86 & 147.48 & 171.55 not normal \\
\hline Jarque-Bera & 65598 & 51074 & 3710 & 2328 & 16665 & 21364 & 353460 & 479957 \\
\hline Probability & 0 & 0 & 0 & 0 & 0 & 0 & 0 & 0 not normal \\
\hline Sum & -21.28 & -25.4 & 42.1 & 57.49 & -725.8 & -512.7 & -26.5 & -15.18 \\
\hline sum sq.dev. & 1334 & 1615 & 6122 & 7298 & 7624 & 7119 & 2689 & 2349 \\
\hline
\end{tabular}

ADF unit root test showed that all variables were stationary at the level. Furthermore, we used the Augmented Dickey-Fuller (ADF) unit roots test to analyze the stationary. The results obtained that all variables were stationary at the level as showed in Table 2. 
Table 2. ADF unit root test : all variables were stationary at the level

\begin{tabular}{ccccc}
\hline Strike & Adj. t-stat & Prob. & Lag lenght \\
\hline-10 & -9.226073 & 0.000 & $*$ & 3 \\
-9 & -9.181502 & 0.000 & $*$ & 3 \\
-2 & -8.156117 & 0.000 & $*$ & 5 \\
-1 & -8.089856 & 0.000 & $*$ & 5 \\
1 & -4.145327 & 0.000 & $*$ & 7 \\
2 & -4.17401 & 0.000 & $*$ & 7 \\
9 & -6.869579 & 0.000 & $*$ & 13 \\
10 & -7.1669 & 0.000 & $*$ & 13 \\
\hline
\end{tabular}

*) stasionary at $5 \%$ of level.

Correlogram showed that all variable still contains an ARCH effect. The next step, we used the correlogram test on each strike to analyze whether an ARCH effect. We used 'lags to include' as much as 36 at level. The results showed that all p-values were below $\alpha$ (p-values $<0.05)$. At this stage, ARCH-GARCH modeling was done on each variable to resolve an ARCH effect. Each variable was analyzed into several models by varying the ARCH-GARCH in the variance and distribution view.

We estimated the ARCH-GARCH to get the optimal model. We searched the lowest value of Akaike info criterion (AIC) and Schwarz criterion (SIC). The lower the value of AIC and SIC, the more optimal the model. If the probability z-stat value is higher than the $\mathrm{z}$ table and lower than the real level of 0.05 , the variables will be significant.

We conducted the ARCH Lagrange Multiplier Test (ARCH-LM Test) to analyze whether the model has a serial correlation and $\mathrm{ARCH}$ effect. If the probability of Chi Square value is lower than its real level $(10 \%) \mathrm{b}$, the variable will contain heteroscedasticity (having serial correlation and ARCH effect). Therefore, it needed to be re-tested the model until it was higher than the actual level (10\%).

We obtained the optimal ARCH-GARCH model on each variable. The model equations of each variable were as follows.

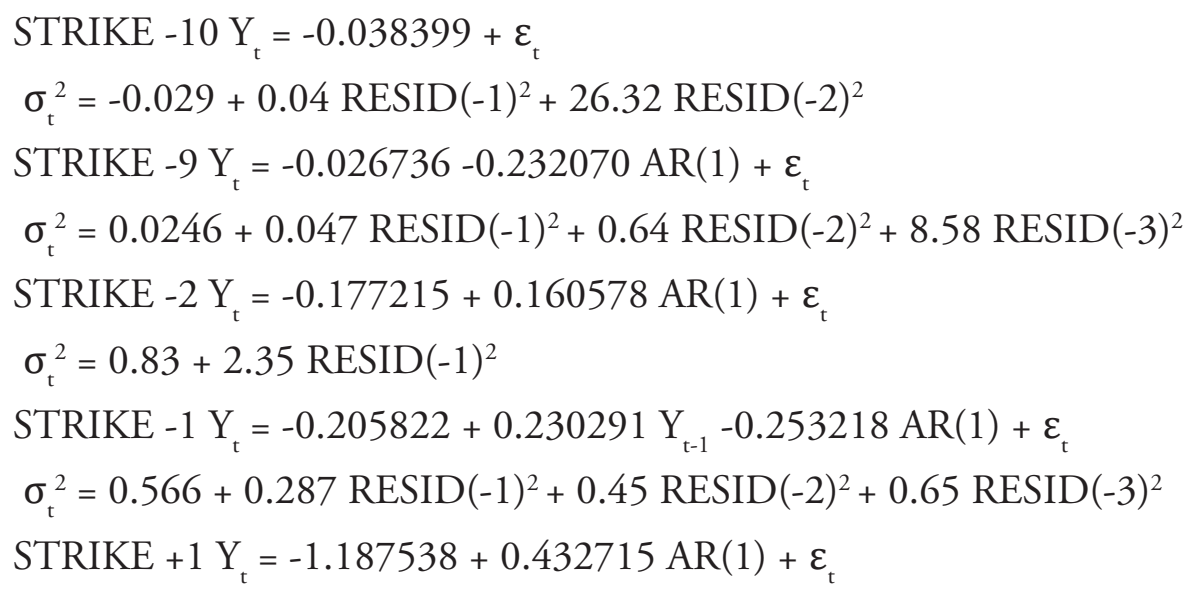




$$
\begin{aligned}
& \sigma_{t}^{2}=13.92+1.48 \operatorname{RESID}(-1)^{2} \\
& \operatorname{STRIKE}+2 Y_{t}=-0.691572+0.452265 \operatorname{AR}(1)+\varepsilon_{t} \\
& \sigma_{t}^{2}=12.84+1.24 \operatorname{RESID}(-1)^{2} \\
& \text { STRIKE }+9 Y_{t}=0.030854-0.048017 \operatorname{AR}(1)+\varepsilon_{t} \\
& \sigma_{t}^{2}=0.000235+30.41 \operatorname{RESID}(-1)^{2}-0.0026 \operatorname{RESID}(-2)^{2} \\
& \operatorname{STRIKE}+10 Y_{t}=0.015243+\varepsilon_{t} \\
& \sigma_{t}^{2}=0.00011+35.47 \operatorname{RESID}(-1)^{2}+0.147 \operatorname{RESID}(-2)^{2}
\end{aligned}
$$

We then calculated Value at Risk (VaR) based on the optimal model equations obtained from ARCH-GARCH analysis. We used the optimal equation model to analyze the existing error term as summarized in Table 3.

Table 3. The absolute value of error term at FOTM strikes and ITM strikes

\begin{tabular}{cccccccc}
\hline strike & $Y_{t}$ & $C$ & $C_{t-1}$ & $Y_{t-1}$ & $c-\operatorname{ar}(1)$ & $\operatorname{ar}(1)$ & $e_{t}$ \\
\hline FOTM & & & & & & & \\
10 & 0.17 & 0.015 & & & & & 0.16 \\
9 & 0.25 & 0.031 & & & -0.048 & 0.03 & 0.22 \\
-9 & 0.13 & -0.027 & & & -0.232 & 0.02 & 0.16 \\
-10 & 0.07 & -0.038 & & & & & 0.11 \\
\hline ITM & & & & & & & \\
2 & -3.21 & -0.692 & & & 0.452 & 0.05 & -2.54 \\
1 & -3.97 & -1.188 & & & 0.433 & 0.05 & -2.80 \\
-1 & 2.85 & -0.206 & 0.230 & -2.17 & -0.253 & 0.04 & 3.56 \\
-2 & 2.19 & -0.177 & & & 0.161 & 0.04 & 2.36 \\
\hline
\end{tabular}

Table 3 shows that the error term in the FOTM strike, ie strike 10, 9, -9 , and -10 are $0.16,0.22,0.16$, and 0.11 respectively. While the error term in ITM strike, i.e., strike 2, $1,-1$, and -2 are respectively equal to $(2.54),(2.80), 3.56$, and 2.36 . These show that the absolute value of the error term at FOTM strikes is much lower than at ITM strikes.

We further analyzed the volatility of each strike based on the optimal model available. The results of our volatility analysis summarized in Table 4 . Table 4 shows that the volatility at FOTM strikes, ie strike $10,9,-9$, and -10 are $0.02,0.02,0.25$, and 0.02 respectively. While the volatility at ITM strikes, i.e. strike $2,1,-1$, and -2 are $12.84,13.92,8.84$, and 0.83 respectively. This result suggests that the volatility at FOTM strikes are much lower than at ITM strikes. 
Table 4. The Volatility at FOTM strikes and ITM strikes

\begin{tabular}{|c|c|c|c|c|c|c|c|c|c|}
\hline strike & $C$ & $c-r(-1)$ & sd var & $\begin{array}{c}\text { Resid } \\
(-1)^{2}\end{array}$ & $c-r(-2)$ & $\begin{array}{c}\text { Resid } \\
(-2)^{2}\end{array}$ & $\begin{array}{l}c-r \\
(-3)\end{array}$ & $\begin{array}{c}\text { Resid } \\
(-3)^{2}\end{array}$ & $\sigma_{t}^{2}$ \\
\hline \multicolumn{10}{|l|}{ FOTM } \\
\hline 10 & 0.0001 & 35.47 & 0.024 & 0.0006 & 0.147 & 0.0006 & & & 0.02 \\
\hline 9 & 0.0002 & 30.41 & 0.026 & 0.0007 & -0.003 & 0.0007 & & & 0.02 \\
\hline-9 & 0.025 & 0.047 & 0.020 & 0.0004 & 0.644 & 0.0004 & 8.58 & 0.03 & 0.25 \\
\hline-10 & -0.029 & 0.004 & 0.018 & 0.0003 & 26.32 & 0.0003 & & & 0.02 \\
\hline \multicolumn{10}{|l|}{ ITM } \\
\hline 2 & 12.84 & 1.24 & 0.042 & 0.0018 & & & & & 12.84 \\
\hline 1 & 13.92 & 1.48 & 0.044 & 0.0019 & & & & & 13.92 \\
\hline-1 & 0.566 & 0.287 & 0.043 & 0.0018 & 0.447 & 0.0018 & 0.65 & 12.70 & 8.84 \\
\hline-2 & 0.825 & 2.349 & 0.039 & 0.0015 & & & & & 0.83 \\
\hline
\end{tabular}

Finally, we analyzed the Value at Risk (VaR) of each strike based on the optimal model available. We assume that the analysis performed on each investment value (w) of 1 U.S. dollar (USD), in 1 month investment period ( $b=25$ days/250 days) with a value of $\mathrm{Z}$ of 1,645. The results of VaR analysis on selling the option on WTI shown in Table 5.

Table 5. The Value at Risk (VaR) at FOTM strikes and ITM strikes

\begin{tabular}{|c|c|c|c|c|c|c|}
\hline strike & W & $\sigma_{t+1}$ & Z & $\sqrt{b}$ & VaR & \\
\hline \multicolumn{7}{|l|}{ FOTM } \\
\hline 10 & 1 & 0.15 & 1.645 & 0.3162 & 0.08 & \\
\hline 9 & 1 & 0.14 & 1.645 & 0.3162 & 0.08 & \\
\hline-9 & 1 & 0.50 & 1.645 & 0.3162 & 0.26 & \\
\hline-10 & 1 & 0.14 & 1.645 & 0.3162 & 0.07 & \\
\hline \multicolumn{7}{|l|}{ ITM } \\
\hline 2 & 1 & 3.58 & 1.645 & 0.3162 & 1.86 & \\
\hline 1 & 1 & 3.73 & 1.645 & 0.3162 & 1.94 & \\
\hline-1 & 1 & 2.97 & 1.645 & 0.3162 & 1.55 & \\
\hline \multirow[t]{3}{*}{-2} & 1 & 0.91 & 1.645 & 0.3162 & 0.47 & \\
\hline & & Average & VaR at & FOTM & 0.12 & 1 \\
\hline & & Average & VaR at & ITM & 1.46 & 12 \\
\hline
\end{tabular}

Table 5 shows that the VaR at FOTM strikes, ie strike 10, 9, -9 , and -10 are 0.08 , $0.08,0.26$, and 0.07 respectively. The average value of VaR in the FOTM strike is 0.12 . It means that for every one USD invested on selling the option on WTI at each FOTM strike, i.e., strike $10,9,-9$, and -10 for one month has a risk of $0.08,0.08,0.26$, and 0.07 USD respectively. The average value of $\mathrm{VaR}$ in the FOTM strike is 0.12 USD. 
While VaR at ITM strikes, ie strike $2,1,-1$, and -2 are $1.86,1.94,1.55$, and 0.47 respectively. The average value of VaR in the ITM strike is 1.46 . It means that for every one USD invested on selling the option on WTI at each ITM strike, i.e., strike 2, 1, -1, and -2 for one month has a risk of $1.86,1.94,1.55$, and 0.47 USD respectively. The average value of $\mathrm{VaR}$ in the ITM strike is 1.46 USD.

The average VaR at FOTM strike is 0.12 , and the average VaR at FOTM strike is 1.46 . It shows that the VaR at ITM strike is 12 times riskier than at FOTM strike. The descriptive statistical analysis and VaR values could show in Table 6.

Table 6. Risk of FOTM strike was much lower than ITM

\begin{tabular}{|c|c|c|c|c|c|c|c|c|}
\hline Strike & Obs & $\mathbf{N}(+)$ & $\%$ & $N(-)$ & $\%$ & $\operatorname{Max}(\%)$ & Min (\%) & VaR \\
\hline \multicolumn{9}{|l|}{ FOTM } \\
\hline 10 & 397 & 376 & 95 & 21 & 5 & 3.98 & -38.77 & 0.08 \\
\hline 9 & 397 & 368 & 93 & 29 & 7 & 4.34 & -39.86 & 0.08 \\
\hline-9 & 397 & 376 & 95 & 21 & 5 & 3.81 & -19.45 & 0.26 \\
\hline-10 & 397 & 382 & 96 & 15 & 4 & 3.37 & -18.42 & 0.07 \\
\hline \multicolumn{9}{|l|}{ ITM } \\
\hline 2 & 397 & 170 & 43 & 227 & 57 & 7.5 & -46.29 & 1.86 \\
\hline 1 & 397 & 71 & 18 & 326 & 82 & 6.77 & -46.99 & 1.94 \\
\hline-1 & 397 & 239 & 60 & 158 & 40 & 8.56 & -26.15 & 1.55 \\
\hline-2 & 397 & 297 & 75 & 100 & 25 & 7.85 & -25.48 & 0.47 \\
\hline
\end{tabular}

Where Max (\%) is the highest return at each strike, Min (\%) is the most profound loss at each strike, $\mathrm{N}(+)$ is the number of win tradings, $\mathrm{N}(-)$ is the number of loss tradings, Obs is the number of all tradings, VaR valued at risk. FOTM strikes are strikes 10, 9,-9 and -10. ITM strikes are strikes $2,1,-1$ and -2 .

Table 6 explains the results of FOTM strikes in selling option on WTI are as follows. First, strike 10 has 397 trades, 376 positive trade returns, and 21 negative trade returns. This strike has a winning probability of $95 \%(=376 / 397)$ and loss probability of $5 \%(=21 / 397)$. This strike has a $3.98 \%$ highest return and $-38.77 \%$ most profound loss. The VaR value of this strike is 0.08 that is much lower than those of ITM strike values.

Second, strike 9 has 397 trades, 368 positive trade returns, and 29 negative trade returns. This strike has a winning probability of $93 \%$ (=368/397) and loss probability of $7 \%$ $(=29 / 397)$. This strike has a $4.34 \%$ highest return and $-39.86 \%$ most profound loss. The VaR value of this strike is 0.08 that is much lower than those of ITM strike values.

Third, strike -9 has 397 trades, 376 positive trade returns, and 21 negative trade returns. This strike has a winning probability of $95 \%(=376 / 397)$ and loss probability of $5 \%$ $(=21 / 397)$. This strike has a $3.81 \%$ highest return and $-19.45 \%$ most profound loss. The VaR value of this strike is 0.26 that is much lower than those of ITM strike values. 
Fourth, strike -10 has 397 trades, 382 positive trade returns, and 15 negative trade returns. This strike has a winning probability of $96 \%(=387 / 397)$ and loss probability of $4 \%$ $(=15 / 397)$. This strike has a $3.37 \%$ highest return and $-18.42 \%$ deepest loss. The VaR value of this strike is 0.07 , which is much lower than those of ITM strike values.

Table 6 also explains the results of ITM strikes in selling option on WTI are as follows. First, Strike 2 has 397 trades, 170 positive trade returns, and 227 negative trade returns. This strike has a winning probability of $43 \%(=170 / 397)$ and loss probability of 57\% $(=227 / 397)$. This strike has $7.5 \%$ highest return and $-46.29 \%$ most profound loss. The VaR value of this strike is 1.86 that is much higher than those of FOTM strike values.

Second, strike 1 has 397 trades, 71 positive trade returns, and 326 negative trade returns. This strike has a winning probability of $18 \%(=71 / 397)$ and loss probability of $82 \%$ $(=326 / 397)$. This strike has a $6.77 \%$ highest return and $-46.99 \%$ most profound loss. The $\mathrm{VaR}$ value of this strike is 1.94, which is much higher than those of FOTM strike values.

Third, Strike -1 has 397 trades, 239 positive trade returns, and 158 negative trade returns. This strike has a winning probability of $60 \%(=239 / 397)$ and loss probability of $40 \%$ $(=158 / 397)$. This strike has an $8.56 \%$ highest return and $-26.15 \%$ most profound loss. The $\mathrm{VaR}$ value of this strike is 1.55 that is much higher than those of FOTM strike values.

Fourth, strike -2 has 397 trades, 297 positive trade returns, and 100 negative trade returns. This strike has a winning probability of $75 \%(=297 / 397)$ and loss probability of $25 \%$ $(=100 / 397)$. This strike has a $7.85 \%$ highest return and $-25.48 \%$ most profound loss. The VaR value of this strike is 0.47 that is higher than those of FOTM strike values.

This research used ARCH-GARCH method. Li et al., (2016) analyzed and compared Brent and WTI using the VaR forecasting performance of GARCH-type models in a short horizon. The results indicate that Brent had the best performance for EGARCH $(1,1)$, while for WTI, APARCH $(1,1)$ and GJR-GARCH $(1,1)$ outperform other GARCH models. He et al., (2012) suggested that estimating Portfolio Value at Risk (PVaR) algorithm outperforms the benchmark Exponential Weighted Moving Average (EWMA) and DCC-GARCH model, in terms of conventional performance evaluation criteria for the model reliability. Marimoutou et al., (2009) applied both unconditional and conditional EVT models to forecast Value at Risk and GARCH $(1,1)$ model provided equally good results, as well as the combining of the two procedures.

The risk analysis in this study used the value at risk (VaR) method. Raj \& Raj (2017) explain that VaR can be used to diversify the portfolio and thus can reduce the risk encountered. Different banks VaR values are calculated and compared. From the results, it can show that VaR values fluctuate through the years from 2013 to 2017. State Bank of India comparatively managed risk effectively. Bilir (2016) calculated VaR value of the portfolio by using the variance-covariance approach of $\mathrm{VaR}$ models and decomposed total risk as systematic and idiosyncratic portions. Oetomo et al., (2016) design accurate and practical method to measure daily stock market risk using Value at Risk model and resume that the Normal VaR best used in markets with a less skewed distribution such as Malaysia (MYX) and Singapore (SGX). 
Barone-Adesi et al., (2016) extracted the 2014-2015 daily option implied VaR and CVaR from the WTI prices and the writing options. They were able to anticipate unexpected changes in the distribution of returns, which would have been unpredictable with standard models. Liu (2012) estimated a VaR for options by extension of the delta-gamma method and explained that $\mathrm{VaR}$ misestimating was more significant for put options and were less significant for call options. He (2012) calculated option portfolio VaR using Monte Carlo simulation under a risk-neutral stochastic implied volatility model and explained that the model produced more accurate results by taking into account nonlinearity, the passage of time, non-normality and changing of implied volatility. Su (2010) examined the one-dayahead VaR forecasting performance using daily spot prices of Brent and WTI crude oil data. Capinski (2009) analyzed VaR using put option and showed that hedging with put options was more effective than hedging with forwarding contracts.

Other researchers have not done the use of ARCH-GARCH and VaR method in the risk analysis of the selling option on WTI investment, so this supports the novelty of this study. This research of option selling on WTI could directly contribute to the development of management science and investment. The results of this study added to the discourse of knowledge about selling option investment, to increase the amount of research in this field, and could introduce more selling options investment to the stakeholders.

The results showed that the investment selling option at the FOTM strike had a much lower risk than that at the ITM strike. This result supported previous research conducted by several researchers. Asianto (2014) compared the FOTM and ITM strike position, and the result showed that the risk of selling options at FOTM strikes position was lower than that at ITM. Berkovich \& Shachmurove (2013) described the performance of selling a put option on SPX above the market. The selling option on index accepted lower returns at lower risk (Li, 2013). Welborn (2013) explained that the underlying delivery regulations on the naked option in the US options market were made unless it has filled out the form. Cordier \& Gross (2009) explained that selling options on futures at FOTM strikes if done in the FOTM strike way would have a lower risk than ITM. Zerenner \& Chupka (2008) explained that the selling option in a conservative way preferred than buying option.

This finding supported the existing theories. The distances of strikes of 10, 9, -9 and -10 (FOTM strikes) against to strike 0 were further than strikes of 2, 1, -1 and -2 (ITM strikes). The price of WTI normally fluctuated past the ITM strike, so the ITM strike was very risky. In contrast, the WTI price did not fluctuate normally exceed than six strikes, so the position of this FOTM strike was relatively safe (Asianto, 2014; Cordier \& Gross, 2009). The result of this study has been following the existing option theory that the value at risk of FOTM strikes was much lower than at the ITM strikes position in selling the option on WTI investment. The further the strike was from strike 0 , the less the risk was.

Selling options on WTI at FOTM strikes at low volatility can be considered to be opened as a conservative investment. We could decrease the risk by choosing the appropriate strikes according to market prediction. If we predict the market moves up, we will do the selling put option on WTI at FOTM strikes. Otherwise, If we predict the market goes down, we will do the selling call option on WTI at FOTM strikes. The risk of the strike position 
that opposite the market view was lower than the risk of the strike position that was similar to the market view.

Abel et al., (2014) explained that the business cycle was persistent. Subsequent declines followed each economic downturn; each economic growth followed by subsequent growth. This condition made volatility to increase drastically. Therefore, if we predict that the market in turbulence, we will not do the selling option, but if there are already the selling option trades opened in suddenly high volatility, the trades should be closed to avoid a spike risk in investment.

\section{Conclusion}

Empirical results indicate that during the study period the value at risk of FOTM strikes is much lower than at the ITM strikes position in selling the option on WTI investment. The further the strike is from the at the money position, the less the risk is. Selling options on WTI at FOTM strikes can consider for decreasing the risk and increasing the performance. These results have important implications that economics; trade policymakers and stakeholders should prioritize the risk analysis first before analyzing profitability. The lowest risk of FOTM strikes of selling option on WTI investment should notice. Knowing the level of FOTM strike risk could increase the performance of investing conservatively.

This study can provide significant input to the financial management literature that the selling option on WTI at FOTM strike investment has a low-risk level. This study can be taken into consideration by policymakers to implement the investment policies and can use as an underlying WTI hedging tool. Investors can apply low-risk investments to increase investment performance conservatively. This study has limited data. Subsequent research can do with a broader range of data, more specific periods such as in a particular crisis period, or with different underlying.

\section{References}

Abel, A. B., Bernanke, B. S., \& Croushore, D. (2014). Macroeconomics. New Jersey: Pearson Education.

Asianto, A. (2014). Analisis Kinerja Empat Strategi Dasar Opsi Minyak Mentah West Texas Intermediate (Performance Analysis of Four Basic Strategy of Option on West Texas Intermediate Crude Oil). (Unpublsihed Thesis). Jakarta: Universitas Trisakti.

Augen, J. (2010). Day Trading Options: Profiting from Price Distortions in Very Brief Time Frames. New Jersey: FT Press.

Barone-Adesi, G., Legnazzi, C., \& Sala, C. (2016). WTI Crude Oil Option-Implied VaR and CVaR: an Empirical Application (Swiss Finance Institute Research Paper No. 16-53). https://doi.org/10.2139/ssrn.2737368

Behmiri, N. B., \& Manso, J. R. P. (2013). Crude Oil Price Forecasting Technique: a Comprehensive Review of a Literature. Alternative Investment Analyst Review, 2(3), $30-48$. 
Berkovich, E., \& Shachmurove, Y. (2013). An Error of Collateral: Why Selling SPX Put Options May not be Profitable. Journal of Derivatives, 20(3), 31-42.

Bilir, H. (2016). Measurement on a Diversified Portfolio: Decomposition of Idiosyncratic Risk in a Pharmaceutical Industry. European Journal of Business and Management, 8(6), 35-40.

Bollerslev, T. (1986). Generalized Autoregressive Conditional Heteroskedasticity. Journal of Econometrics, 31, 307-327.

Capinski, M. J. (2009). Managing Value at Risk Using Put Options (AGH, Faculty of Appl. Math. Research Report 2010/05).

Clarke, J., \& Clarke, D. (2012). A Beginner's guide to Trading Options for Success: Options Made Simple. Melbourne: Wrightbooks.

Cordier, J., \& Gross, M. (2009). The Complete Guide to Option Selling: How Selling Options can Lead to Stellar Returns in Bull and Bear Markets (2nd editio). New York: McGraw Hill.

He, K., Lai, K. K., \& Xiang, G. (2012). Portfolio Value at Risk Estimate for Crude Oil Markets: a Multivariate Wavelet Denoising Approach. Energies, 5, 1018-1043. https:// doi.org/10.3390/en5041018

He, P. (2012). Option Portfolio Value at Risk Using Monte Carlo Simulation Under a Risk Neutral Stochastic Implied Volatility Model. Global Journal of Business Research, 6(5), $65-72$.

Jorion, P. (2011). Financial Risk Manager Handbook Plus Test Bank (6th editio). New Jersey: John Wiley \& Sons.

Li, B. (2013). Two Essays on Crude Oil Futures and Option Markets. Houston: University of Houston.

Li, Y. X., Lian, J. G., \& Zhang, H. K. (2016). Forecast and Backtesting of VAR Models in Crude Oil Market. Research and Review: Journal of Statistics and Mathematical Sciences, 2(1), 131-140.

Liu, S. I. (2012). Estimations on VaR for Options: Extension of Delta-Gamma Method. IJRRAS, 14(1), 40-50.

Marimoutou, V., Raggad, B., \& Trabelsi, A. (2009). Extreme Value Theory and Value at Risk: Application to Oil Market. Energy Economics, 31(4), 519-530. https://doi. org/10.1016/j.eneco.2009.02.005

Mugwagwa, T., Ramiah, V., Naughton, T., \& Moosa, I. (2011). The Efficiency of The BuyWrite Strategy: Evidence from Australia. International Finance Markets, Institutions, and Money, 22, 305-328. https://doi.org/10.1016/j.intfin.2011.10.001

Oetomo, B., Achsani, N. A., \& Sartono, B. (2016). Forecasting Market Risk in ASEAN-5 Indices using Normal and Cornish-Fisher Value at Risk. Research Journal of Finance and Accounting, 7(18), 28-38.

Raj, K. B., \& Raj, K. L. S. (2017). A Comparative Analysis Among Indian Commercial Banks (Public \& Private) and a Foreign Bank Using Var (Value-At-Risk) Model. European Journal of Business and Management, 9(31), 1-10. 
Saliba, A. J., Corona, J. C., \& Johnson, K. E. (2008). Option Strategies for Directionless Markets: Trading with Butterflies Iron Butterflies and Condors. New York: Bloomberg Press.

$\mathrm{Su}$, J. B. (2010). Value-at-Risk Forecasts in U.S. Crude Oil Markets. China University of Science and Technology, 42, 161-175.

Summa, J. F., \& Lubow, J. W. (2002). Option on Future: New Trading Strategies. New York: John Wiley \& Sons.

Thomsett, M. C. (2008). Winning with Options: The Smart Way to Manage Portfolio Risk and Maximize Profit. New York: Amacom.

Welborn, J. W. (2013). Three Essays on Naked Short Selling and Fails to Deliver. (Unpublished Dissertation). Virginia: George Mason University.

Zerenner, E., \& Chupka, M. (2008). Naked Puts: Power Strategies for Consistent Profits. Maryland: Marketplace Books. 